\title{
PENGARUH MIE INSTAN BAGI KESEHATAN ANAK KOS DI JALAN GARUDA INDUK,KEC.PADANG UTARA,KOTA PADANG
}

\author{
Difha Kencana \\ Jurusan Pendidikan Sosiologi-Universitas Negeri PadangKampus Universitas \\ Negeri Padang Jl. Prof. Dr. Hamka, Air Tawar, Padang.Email: \\ difhakencana46@gmail.com
}

\begin{abstract}
Abstrak
Mi instan adalah salah satu contoh hasil kemajuan teknologi pangan yang banyak di konsumsi oleh Mahasiswa Di Indonesia, termasuk di Kota Padang.Karna mie tersebut sangat banyak digemari mahasiswa,selain murah juga praktis untuk dikosumsi. Dan kita bisa melihat didalam realitas sosial sekarang sangat banyak mahasiswa yg mengandalkan teknologi seperti membeli makanan dengan gojek online,Mereka dengan mudah memesan makanan tanpa harus susah payah membeli makanan keluar, dan sangat cenderung mahasiswa ini memesan makanan yaitu mie. Tujuan penelitian Mengembangkan analisis faktor-faktor yang mempengaruhi pola konsumsi mi instan pada mahasiswa di kota Padang. Metode Penelitian: Penelitian ini menggunakan metode kualitatif, yaitu dengan observasi dan langsung melakukan wawancara. Hasil penelitian menunjukan bahwa untuk mengetahuiseberapa seringkah para mahasiswa mengosumsi mie, Dan apa saja efek samping dari keseringan mengosumsi mie tersebut. Temuan utama penelitian adalah faktor yg memengaruhi mahasiswa untuk mengosumsi mi tersebut karna faktor individu,faktor lingkungan sosial,faktor ekonomi,dan fakor orang tua yg kurang memerhatikan anaknya.
\end{abstract}

Kata kunci: mi instan, mahasiswa,faktor penyebab,efek samping.

\section{Pendahuluan}

Seiring dengan perkembangan zaman, kebutuhan hidup manusia semakin meningkat. Hal ini terjadi pada seluruh kalangan. Disisi lain, kesibukan-kesibukan dalam berbagai aktivitas seperti pekerjaan sering kali membuat kita menomorduakan kebutuhan-kebutuhan pokok, seperti makanan. Hal tersebut rupanya disadari oleh berbagai pengelola badan usaha sebagai peluang untuk mencari keuntungan. Semakin hari badan usaha berlomba-lomba untuk memproduksi bahan makanan mie instan. Banyaknya makanan mie instan yang beredar dipasaran semakin memanjakan konsumen apalagi untuk kalangan mahasiswa.

Terlebih lagi, mahasiswa yang sedang berada pada masa peralihan dari 
masa kanakkanak menuju dewasa yang sibuk dengan hal-hal baru mereka kenal sehingga timbul pola hidup konsumtif yang terkadang berlebihan. Pola berfikir mereka seakan ikut berubah. "kalo ada yang mudah, kenapa harus memilih yang susah?". Dalam sehari seorang mahasiswa mampu mengkonsumsi beberapa jenis makanan mie instan. Makanan mie instan seakan telah mendarah daging dalam diri mereka bahkan ada yang menjadikannya makanan sehari-hari (Afifah, 2012).

Mie instan yang sering kali kita santap, memang sangat terlihat lezat dan cepat untuk disajikan serta harganya yang tidak mahal. Mie instan ini sangat kaya akan karbohidrat, namun kadar vitamin dan mineral sangat rendah sekali. Bentuknya yang keringpun merupakan hasil penggorengan yang kaya akan trans fat yang bisa menyebabkan penyakit jantung koroner karena trans fat ini berperan meningkatkan kolesterol LDL (kolestrol jahat). Selain itu, bagi anda yang gemar menyantap mie instan kuah, tahukah anda bahwa makanan tersebut lebih banyak mengandung MSG (Mono Sodium Glutamat) dan sodium yang sangat tidak baik untuk kesehatan anda. Ada lagi mie instan yang siap saji yang biasanya diseduh dalam kemasan styrofoam. Zatzat berbahaya yang terkandung dalam kemasan bisa berpindah dengan mudah ke makanan karena suhu tinggi (Herwin, 2007).

Styrofoam atau polystyrene telah menjadi salah satu bahan paling populer yang digunakan dalam bisnis pangan, termasuk untuk kemasan mie instan. Bahkan WHO menyebut bahan ini sebagai pemicu kanker (Susanto, 2014). Penelitian yang dilakukan oleh ilmuwan Amerika Serikat menemukan resiko kesehatan yang berbahaya jika anda mengkonsumsi mie instan 2-3 kali seminggu. Dr.Shin yang memimpin penelitian mengatakan mie instan dapat meningkatkan resiko sindrom kardiometabolik seperti jantung, stroke dan diabetes. Padahal penyakit ini merupakan penyebab kematian di seluruh dunia. "Selain mengandung bahan pengawet, mie instan juga memiliki bahan kimia yang disebut bisphenol A (BPA) yang di gunakan untuk mengemas mie dalam wadah styrofoam, "kata Shin pada (Dailymail, 2014).

Penelitian telah menunjukan BPA mengganggu cara hormon mengirim pesan melalui tubuh, khususnya ekstrogen. Maka itu, Dr.Shin sangat menghimbau wanita pada khususnya untuk tidak mengkonsumsi mie instan.'Konsumsi ramen 
relatif tinggi pada populasi Asia, penelitian difokuskan terutama di Korea Selatan. Karena kecenderungan rakyatnya mengkonsumsi mie instan merupakan yang tertinggi di dunia. Dalam beberapa tahun terakhir, buktinya Korea Selatan telah mengalami penigkatan resiko penyakit jantung dan dewasa obesitas" kata Dr.Shin (Susanto, 2014).

Mie instan merupakan salah satu makanan terfavorit warga Indonesia. Bisa dipastikan hampir setiap orang telah mencicipi mie instan atau mempunyai persediaan mie instan dirumah. Bahkan tidak jarang orang membawa mie instan saat keluar negeri sebagai persediaan makanan lokal jika makanan diluar negeri tidak sesuai selera. Saat ini, Indonesia adalah produsen mie instan terbesar didunia. Dalam hal pemasaran, pada tahun 2005 Tiongkok menduduki tempat teratas, dengan 44,3 milyar bungkus, disusul dengan 12,4 milyar bungkus dan Jepang dengan 5,4 milyar bungkus. Namun Korea Selatan mengkonsumsi mie instan terbanyak perkapita, dengan rata-rata 69 bungkus pertahun, diikuti oleh Indonesia dengan 55 bungkus dan Jepang dengan 42 bungkus (Maut, 2011).

Banyak alasan mengapa sebagian besar mahasiswa sangat gemar mengkonsumsi mie instan menurut KTI yang dimuat oleh Halysha Ashryy pada hari sabtu 29 maret 2014. Yang telah menyebarkan angket dan diapun mendapatkan beberapa alasan mengapa masyarakat Indonesia sangat menggemari mie instan. Sebagian besar beranggapan bahwa mie instan adalah makanan yang praktis dan mudah penyajiannya. Sebagian lagi beranggapan mie instan adalah makanan yang murah dan mudah didapat (Ashryy, 2014).

Dibalik kelezatan rasa yang diberikan oleh mie instan, terdapat beberapa zat-zat berbahaya yang dapat bedampak buruk terhadap kesehatan tubuh. Namun banyak orang yang tidak mengetahui bahkan mengabaikan. Mengkonsumsi mie instan dalam jumlah banyak dan jangka waktu yang lama dapat menimbulkan penimbunan zat adiktif yang terkandung dalam makanan instan pada tubuh mereka. Saat ini banyak mahasiswa yang menderita penyakit maag, radang dan berbagai penyakit yang menyerang alat pencernaan. Hal ini tentu tidak lepas dari kebiasaan mereka mengonsumsi makanan mie instan (Afifah, 2012).

Menurut studi pendahuluan yang peneliti lakukan pada tgl 26 September 
2014 dengan jumlah sampel 10 dengan hasil 4 Mahasiswa mengetahui tentang bahaya mengkonsumsi mie instan dan 6 Mahasiswa tidak mengetahui bahaya mengkonsumsi mie instan. Oleh karena itu, peneliti tertarik untuk mengetahui lebih dalam tentang gambaran tingkat pengetahuan mahasiswa/i tentang bahaya mengkonsumsi mie instan di Akademi Keperawatan Husada Karya Jaya.

\section{Kajian Pustaka}

Menurut Wahyu Pamungkas (2003:87), Kalangan mahasiswa (terutama mahasiswa kos) merupakan salah satu konsumen favorit mie instant karena menggunakan mie instant sebagai sarana (strategi mengatasi kebutuhan selama menempuh studi), sebagai suatu pilihan pada saat-saat tertentu seperti anggaran habis, malas makan nasi, makan pagi, makan malam, ataupun menikmati sensasi rasa yang ditawarkan mie instant. Pilihan konsumsi mahasiswa kos terhadap mie instant merupakan cerminan gaya hidup terhadap produk yang peka terhadap tuntutan zaman. Konsumsi mie instant sebagai salah satu pilihan rasional dalam mengikuti perkembangan zaman yang penuh dengan segala sesuatu yang cepat, praktis, efisien, dan ekonomis.

Dengan demikian permasalahan yg terjadi di kalangan remaja bagi kesehatannya sangatlah rentan,dikarenakan mahasisa sekarang banyak yg mengikuti perkembangan zaman yg serba praktis atau cepat saji,selain itu faktor yg menggemari mahasiswa memakan mie karna malas masak dan mengirit biaya untuk kelangsungan hidupnya.

Mie instant belum dapat dianggap sebagai makanan penuh (wholesome food) karena belum mencukupi kebutuhan gizi yang seimbang bagi tubuh. Mie yang terbuat dari terigu mengandung karbohidrat dalam jumlah besar, tetapi sedikit protein, vitamin, mineral dan serat. Hal yang perlu diingat adalah fungsi pemenuhan kebutuhan gizi mie instant hanya dapat diperoleh jika ada penambahan sayuran dan sumber protein. Jenis sayuran yang dapat ditambahkan adalah wortel, sawi, tomat, kol, atau tauge. Sumber proteinnya dapat berupa telur, daging, ikan, tempe, atau tahu. Satu takaran saji mie instant berjumlah 80 gram mampu menyumbangkan energi sebesar $400 \mathrm{kkal}$, yaitu sekitar $20 \%$ dari total kebutuhan energi harian (2.000 kkal). Energi yang disumbangkan dari minyak berjumlah sekitar 170-200 kkal. Hal lain yang terkadang kurang disadari adalah kandungan minyak dalam mie instant yang dapat mencapai $30 \%$ bobot kering. Hal ini perlu diwaspadai bagi penderita obesitas atau orang yang sedang dalam program 
penurunan berat badan. Jadi, wajar jika mie instant disukai, karena selain praktis, cepat, lezat dan murah (Lina R, 25 Mei 2005).

Tentu dari kutipan diatas dapat kesimpulan bahwa mie instan adalah makanan yg sedikit gizi dikarenakan didalam komposisi mie cuman terdapat terigu dan tidak mengandung protein dan juga didalam bumbu mie tersebut tidak terdapat vitamin,dikarenakan tidak ada sayur,ikan,tempe,wortel,dll.Tidak seperti kita memakan nasi yg begitu banyak protein yg cukup dan selain itu mie tersbut juga sering dikomsumsi oleh orang yg obesitas karna mie juga bisa menjadi progam makanan penurunan berat badan.

Mie instant bila dikonsumsi dalam jumlah banyak dan sering juga dapat menyebabkan gangguan kesehatan, karena dalam mie instant mengandung bahanbahan rekayasa yang dibuat agar mie tersebut memiliki rasa yang hampir mirip dengan bumbu yang sebenarnya, walaupun bahan-bahan tersebut diperbolehkan untuk dikonsumsi oleh manusia, tetapi apabila dikonsumsi dalam kurun waktu tertentu dan frekuensi yang cukup tinggi bisa menyebabkan kelainan fungsi (www.forumgaul.com). Sedangkan menurut Marius Widjajarta dari Yayasan Pemberdayaan Konsumen Kesehatan Indonesia (YPKKI) mengungkapkan bahwa mengkonsumsi vetsin (MSG) dalam jangka panjang dan terus menerus dalam makanan dapat menyebabkan ketidakmampuan belajar (Republika, 2004).

Dari penjelasan diatas dapat disimpulkan bahwa mie sangatlah tidak baik jika dikomsumsi sering atau dalam jangka waktu panjang dikarenakan didalam bumbu mie tersebut terdapat sekali banyak bahan bahan yg tidak sehat seperti vetsin,dan jika mengomsumsi mie terlalu sering bisa menyebabkan ketidakmampuan belajar dikarenakan vetsin tadi tersebut meyerang otak kita yg membuat susah belajar.

\section{Metode Penelitian}

Penelitian ini dilakukan di kosan pak Rt dijalan garuda induk,karna ada beberapa mahasiswa disana yg sering mengomsumsi mie,dampak pengaruhnya bagi kesehatan mahasiswa tersebut.Peneletian ini dilakukan dengan pendekatan kualitatif,Dengan menganalisis tentang dampak buruk mie bagi kesehatan 
mahasiswa.Pendekatan kualitatif ini ini diartikan penelitian yg menghasilkan data deskriptif mengenai lisan maupun kata kata dan tingkah laku yg telah diamati dari orang orang yg diteliti.

Lincoln dan Guba (1985 : 25) mengemukakan bahwa dalam pendekatan kualitatif peneliti seyogianya memanfaatkan diri sebagai instrumen, karena instrumen nonmanusia sulit digunakan secara luwes untuk menangkap berbagai realitas dan interaksi yang terjadi. Peneliti harus mampu mengungkap gejala sosial di lapangan dengan mengerahkan segenap fungsi inderawinya.

Untuk memperoleh data ini dengan baik, maka sejumlah data di lakukan dengan pengumpulan data dari informan. Subyek dalam penelitian ini adalah mahasiswa yang kos di jalan garuda induk kota Padang selama berlangsungnya wawancara sampai saat ini. Teknik yang dilakukan pemilihan informan adalah purposive sampling, menggunakan teknik ini agar mendapatkan data sesuai dengan topik penelitian. Dalam teknik ini peneliti dengan sengaja memilih informan yang akan memberikan data sesuai dengan tujuan penelitian. informan yang dipilih diharapkan agar dapat menjelaskan dan memberikan penjelasan mengenai bagaimana pengaruh mie instan terhadap kesehatan mahasiswa dikosan pak rt.

Kriteria yang dipilih menjadi informan yaitu (1) Mahasiswa yg kos di kosan pak rt jalan garuda induk(2) Beberapa anak kos yg kos di jalan garuda induk. Sistem pemilihan tiga kriteria ini agar dapat memberikan data yang relevan dan berbeda dari sudut pandang beberapa anak kos di kosan pak Rt jalan garuda induk.

Teknik pengumpulan data dalam penelitian ini adalah oberservasi partisipasi, wawancara mendalam dan studi dokumen. Dan data ini didapat oleh pertanyaan kepada informan yang telah sering mengomsumsi mie tersebut. Studi dokumen yaitu dengan mengumpulkan data-data yang telah ada seperti seberapa banyak mengosumsi mie,seberapa banyak dan apa dampak jika terlalu sering mengosumsi mie tersebut. 
Tujuan dari penelitian ini adalah untuk mengetahui dan memahami bagaimana pengaruh terlalu sering mengosumsi mie tersebut,apa dampak terhadap kesehatan mahasiswa dikosan pak rt jalan garuda induk kota Padang.

\section{Hasil dan Pembahasan}

Mie instan merupakan bentuk makanan saji yg dibuat manusia dengan rasa yg begitu enak sehingga membuat semua orang menjadi ketagihan,apalagi dikalangan remaja seperti anak kos,mereka lebih memilih makan cepat saji dari pada harus memasak makanan yg lebih sehat.

Dari hasi pengamatan maupun survey yang dilakukan mahasiswa tersebut sengaja untuk membeli mie instan berdus untuk mereka simpan sebagai stok mereka di kos, hal ini sudah menjadi kebiasaan bagi para mahasiswa. Dan saya juga mengamati mahasiswa seperti itu bukan karna malas memasak tapi juga ada faktor lain,seperti mereka mengehemat keuangannya,karna dengan memakan mie ia merasa keuangannya merasa leih hemat. Akan tetapi upaya mahasiswa tersebut untuk mengubah pola makan mengomsumsi mie tersebut sangatlah susah karna mereka sudah menjadi kebiasaan dalam memakan mie tersebut. Bisa kita lihat dari lingkungan pesantren selain itu sebagian besar kebersihan kantin/warung sekolah masing jauh dari prinsip hygiene sanitasi makanan. Pihak sekolah akan sulit merobah perilaku warga sekolah (terutama siswa) untuk Hidup Sehat, kalau tidak didukung oleh sarana yang cukup. Masalah kesehatan adalah pengelolaan makanan secara yang kurang baik atau kurang higenis. Banyaknya jumlah masakan yang akan dimasak ternyata terlihat kurang baiknya pengelolaan masakan dapur untuk santri, sehingga banyak ditemukan berbagai macam hal dalam makanan santri seperti rambut. Hal ini menunjukkan kurang bersihnya pengelolaan makanan oleh ibu dapur untuk para santri yang dapat berakibat pada penyakit diare, cacingan, dan disentri, karena kurang bersihnya makanan dan minum yang mereka makan setiap hari. Dan juga mie instan juga menjadi favorit anak santri,menyebabkan kecanduan karna rasa yg sungguh enak yg terkandung didalam bumbu mie tersebut.

Informasi yang coba di dapatkan dari anak kos dikosan pak Rt kamar 4 adalah salah seorang mahasiswa yg kos dijalan garuda induk kec.Padang utara,kota padang Banyak faktor yg bikin saya sering mengosumsi mie tersebut,tetapi salah satu faktornya adalah uang,dikarenakan saya anak kos jadi saya berusaha melakukan pengehematan untuk hidup saya dirantau orang ini.Dan saya juga sangat takut karna seringnya mengosumsi mie tersebut berpengaruh akan kesehatan saya,karna mie itu sangat membahayakan usus saya,tapi mau tidak mau itu terpaksa. (Abenk,wawancara,17 oktober 2019)

Dari wawancara diatas dapat disimpulkan bahwa mahasiswa tersbut lebih menyayani uangnya dari pada kesehatannya,dia tahu bahwa mie tersebut tidak baik 
dikosumsi dengan sering tetapi dia tetap juga memakan mie itu dengan sering,dikarenakan faktor ekonominya.

Pada hasil wawancara kedua saya mendapatkan informan, berupa informasi darianak kos kamar 3 di kos pak Rt jalan garuda induk

Sebenarnya saya tidak terlalu suka mie,tetapi saya sangat malas untuk memasak,dikarenakan mie tersebut sangat instan dan praktis jadi saya lebih suka mengosumsi mie tersebut,dari pada ribet dengan memasak atau membeli makanan dengan harga mahal,mending saya memilih memakan mie,selain harga terjangkau juga praktis dan simpel.(Faisal,wawancara,18 oktober 2019)

Dari wawancara diatas dapat disimpulkan bahwa mie selain harganya terjangkau juga pembuatannya simpel,tidak ribet,dan praktis,jadi disitu mahasiswa banyak menyukai mengosumsi mie,walaupun tidak suka kali dengan mie tetapi karna kepraktisannya menjadi kegemaran dikalangan mahasiswa.
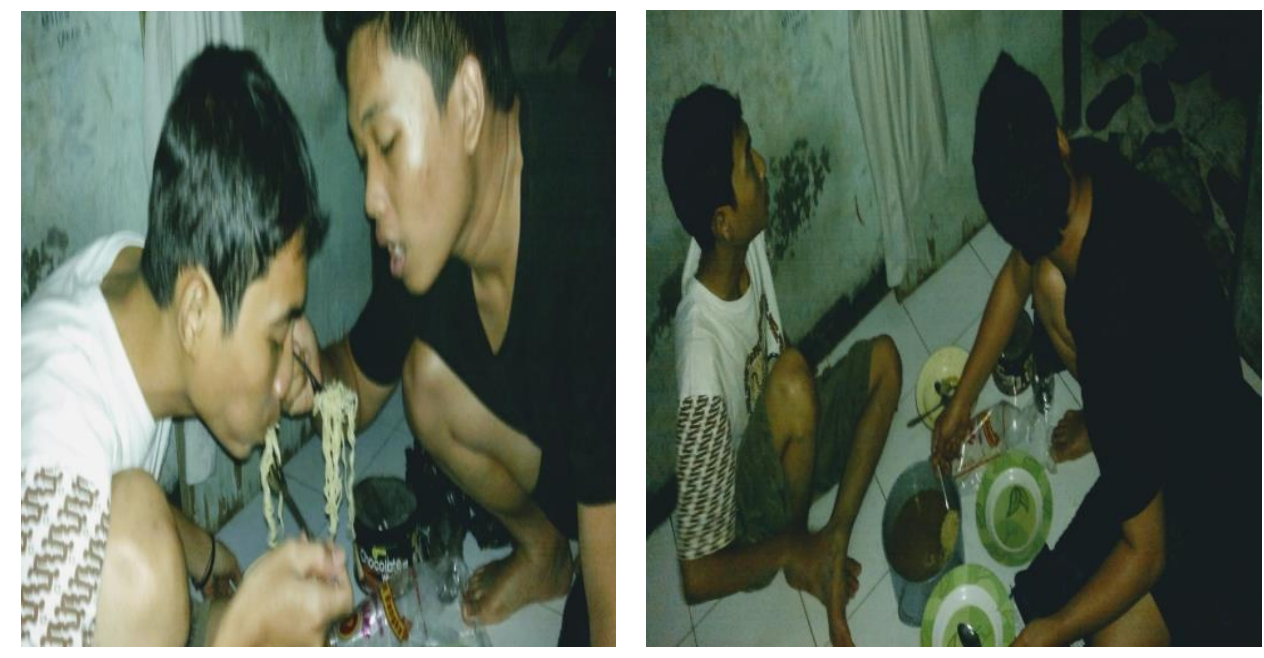


\section{Penutup}

Banyak dari kalangan masyarakat menyukai mie instan karena proses pembuatannya yang sederhana dan harganya yang terjangkau. Dibalik rasanya yang enak ternyata mie instan memiliki banyak bahaya bagi kesehatan tubuh karena adanya kandungan lilin, MSG dan natrium yang berbahaya bagi kesehatan.Dampak akibat terlalu sering mengkonsumsi mie instan itu dapat memyebabkan kurangnya metabolisme dalam tubuh, penghambatan penyerapan nutrisi bahkan bisa mengakibatkan kanker.

Hasil penelitian menyimpulkan bahwa menjaga pola makan agar tetap sehat dan seimbang sangatlah penting khususnya di kalangan remaja yang memiliki pola makan konsumtif. Hal ini dikarenakan ketersediannya bahan makanan instan yang sangat banyak baik di sekolah, di rumah maupun saat melakukan perjalanan jauh.Selain nikmat tetapi dampaknya sangat besar yaitu kecanduan racun yang seharusnya tidak di konsumsi. Efek yang nyata adalah tubuh para remaja yang digroggoti secara perlahan dan akan menyebabkan penyakit-penyakit yang berbahaya dalam tubuhnya. 


\section{Daftar Pustaka}

Anam, C dan Handajani, S. 2010. Mie (Cucurbita moschata) dengan antioksidan dan pewarna alami. Caraka Tani XXV No.1

Ahmad Sujudi.2002."Bahan Pengawet dan Penyedap Makanan Picu Timbulnya.

Djiteng Roedjito. (1988). Kajian Penelitian Gizi. Jakarta: Mediyamata.

Frietag, Herry L.M. dan Oktaviani, Prima. 2010. Diet Seru Ala Remaja Yogjakarta: Galangpress.

Iryanto, Kus dan Waluyo, Kusno. 2004. Gizi dan Pola Hidup Sehat. Bandung: Yrama Widya.

Hidayat, M. (2014). Problematika Kesehatan Di Pesantren (Suatu Kajian Proses Dalam Pendidikan Kesehatan Budaya Di Pesantren X). Jurnal Antropologi: Isu-Isu Sosial Budaya, 16(1), 25-36.

Masri Singarimbun dan Effendi. 1989. Metode Penelitian Survei. Jakarta : LP3ES.

Raharja, dkk. 1993. Proses Pembuatan Mie Instant. Indofood. Jakarta.

Sarkim, Linda., Nabuasa, Engelina., Limbu, Ribka. 2010. Perilaku Konsumsi Mie Instan Pada Mahasiswa Fakultas Kesehatan Masyarakat UNDANA Kupang yang Tinggal di Kos Wilayah Naikoten 1. MKM, 05, 1.

Soetjiningsih. 2004. Tumbuh Kembang Remaja dan Permasalahannya. Jakarta: Sagung Seto. 